\title{
Marek Piotr Chojnacki OCist., Sacramentis Ecclesiae communicare. Chrzest i Eucharystia jako sakramentalne źródła życia chrześcijańskiego wedtug świętego Bernarda $z$ Clairvaux, tłum. M. Małecka, G. Małecka, Wydawnictwo Benedyktynów TYNIEC, Kraków 2012, 476 pp. (Źródła Monastyczne, 59)
}

The doctoral thesis, originally published in Italian in 2003 in Rome, is a deep elaboration on the teachings of St. Bernard on the subjects crucial for dogmatics, liturgics, spiritual life in general, especially in monastic circles.

The dissertation is divided into three parts. The first part focuses on the historical and intellectual context of the thought of St. Bernard concerning sacramental identity. It consists of two chapters. The first one is devoted to St. Bernard of Clairvaux as a representative of Monastic Theology. The term, discussed by J. Leclercq in more detail, shows the difference between the approach to explaining and deliberating on religious issues between the authors from monastic circles, who in a way follow the methods of the Church Fathers, elaborating on problems with reference to the Holy Scripture; and scholastic authors, who use methods based on logic and scholarly systems of argumentation. The author characterises the Renaissance of the $12^{\text {th }}$ century and, in its stream, St. Bernard, who is presented as a theologian and a master responding to the expectations 
of his time in the light of contemporary research. In the second chapter the liturgical and sacramental context of the development of St. Bernard's theological thought is presented: the liturgical aspect of The Rule of Saint Benedict as the fundament of the sacramentological thought of St. Bernard, the liturgical ambience of the time and the Cistercian Order, as well as main sacramental concepts of that period.

Part two comprises of the analysis of St. Bernard's text concerning Baptism and the Eucharist. It consists of two chapters focusing on the afore - mentioned sacraments. Baptism for St. Bernard is a ritual source of Christian life, which he presents discussing the need of the sacrament of faith, which is the sacrament of righteousness and salvation, and its meaning in Christian life. In chapter four, being the second chapter of this part of the work, he presents the Eucharist as the ritual source of spiritual and moral life of Christians on their way to God, the ritual source of life of the redeemed human being, moral and social life of Christians.

The third and last part of the text is the evaluation of the Baptismal and Eucharistic theology of St. Bernard and the presentation of its current significance. It contains one chapter presenting the unity of the Eucharist and Baptism with the spiritual and ethical life of man: the summary of St. Bernard's approach to the sacraments of Baptism and Eucharist, as well as the outline of Bernard's reflection on the two sacraments. It shows the thoughts shaped in the Middle Ages, but open to issues universally referring to life and enhancing the ecumenical dialogue, also in the contemporary world.

The paper finishes with conclusions accurately summarising its individual chapters. The vast bibliography shows the author's diligence and conscientiousness. The Biblical Index helps identify the texts used by St. Bernard with ease. The reader can also reach for the Indices of St. Bernard's works and proper names.

The author's work and assignments made it impossible for him to translate the text himself. The translators used clear, comprehensible and theologically correct language in their work. A slight drawback for the Polish reader is the lack of information on Polish translations of texts used in other languages. 
This valuable dissertation gives new insight into St. Bernard's sacramentological thought and its reference to Christian life. It emphasises the significance of liturgical acts and their consequences. It reminds that the sacrament of Baptism and the sacrament of the Eucharist are the bases of the way along which Christ, the Incarnate Son of God, leads us to the house of the Father. 
